\title{
Strengthening the Marketing Strategies for the Traditional Property Developer in Malaysia
}

\author{
Woon Siew Lim1, Norazah Mohd Suki2 \\ 1,2 Othman Yeop Abdullah School of Business, Universiti Utara Malaysia \\ Corresponding author:woonsl@gmail.com
}

Received: 27 September 2019 Revised: 13 May 2020 Accepted: 14 May 2020 Published: 31

December 2019

\begin{abstract}
During the global economic downturn not only affecting Malaysia's property industry but it was also impacted the global property industry, during the economic downturn was increasingly market competitive eventually the Malaysia property industry is even more challenging with over supplying properties as more and more building been completed in the markets but the sales is slow during economic downturn. Therefore, an effective marketing plan is integral aspect even for all types of businesses which also been widely recognized and acknowledged, as an effective marketing plan have significant positive impact to all kinds of businesses. The goal of this case study is to strengthening the marketing strategies with access and examine the marketing strategies for the traditional property developer firm in Malaysia with the targeted company name is 'S', a direct interview with the marketing team was applied to examine the company marketing strategy. Strengthening of the marketing strategies plan with considering the marketing factors such as marketing positioning, marketing recognition, diverse customer base, marketing strategies effectiveness, internal environment, promotion strategies, promotion budgets, and product design and technology. The finding of this case study is providing a solution for strengthening the marketing strategies for the traditional property developer firms even during the economic downturn which able to strengthen and improve the company market share and reduce the burden with selling off the completed balance unsold stock units, as this traditional property developer firm need to upgrade, update and improvement their marketing strategies.
\end{abstract}

Keywords: Industry, Property, Marketing Strategies, Market Recognition, Positioning 
Global Business Management Review, 2020

JUNE 2020

http://gbmr.oyagsb.uum.edu.my

\subsection{INTRODUCTION}

The global property markets were poised to slow down, especially in the residential housing development, but in the European countries and parts of Asia's countries were still maintained a strong rising in property prices. However, during the statistic survey having more than half of the countries showed weaker markets during the year 2018 compared to the previous years, unfortunately, China, Sweden, Turkey and most of the Middle East were experienced either property price falls or a sharp deceleration of price rises (Lalaine, 2018). According to Xue (2019) Malaysia's property market did not show any weaker or price falls but expects to be further stagnation unless can see some anticipation improvements in one to two years, even the new Malaysian Government was form in 2018 with introduced new policies and incentives aimed at the property market such as the National Housing Policy 2.0 and Property Crowdfunding platform. Marketing plan is significantly crucial during the economic down-turn with the stagnation property market in Malaysia, it has been around the World since humans have started selling things (Tang, Ng \& Skitmore, 2019). Therefore, marketing strategies are an integral aspect and an important factor for each and every business, some of the traditional companies were not concerned about their marketing strategies with lacked focus on how strategic of their marketing strategies, using the outdated marketing strategies plan for years which resulted miss-out the new customer targets and unable to increase their sales value (Trusov, Bucklin \& Pauwels, 2009). The update and refresh marketing strategies plan are reasonably crucial for all businesses; it should be strategically upgrading time to time to suit the market needs and adopt into the market trends.

The 'S' company was a traditional property developer firm as one of the leading property market players in the building industry in Malaysia, since the 'S' was founded in 1950's as a progressive building contractor further in early 90's the company has expanded their business into property development projects in Klang Valley and East Malaysia in Sabah. The 'S' should able to be the leader of the industry with over 60 years' experience in the building industry, however they still did not receive any award or reward from property competition for all the projects as competition awards can positively be part of the marketing tools and branding purposes. Hence the 'S' did not focus on marketing strategies and branding, just only remained the traditional sales method with the slow and steady sale value which did not achieve the shareholders' expectations. 
Global Business Management Review, 2020

JUNE 2020

http://gbmr.oyagsb.uum.edu.my

\subsection{BACKGROUND OF PROPERTY MARKET}

The worldwide property market performance has experienced upward since 2011 and a decline from 2008 to 2010 further decline in between 2014 to 2015. The global property markets were poised to slow down, especially in the residential housing properties. However, in the European countries and parts of the Asia countries were still maintained high rising price (Zull and Masron, 2016). The statistic survey having more than half of the countries showed weaker markets during the year 2018 compared to the previous years, unfortunately, China, Sweden, Turkey and most of the Middle East were experienced either property price falls or a sharp deceleration of price rises (Lalaine, 2018).

The countries that have strong property markets during the year to Q3 2018 were Malta $(+12.86 \%)$, Hong Kong (+11.11\%), Netherlands (+8.45\%), Singapore (+7.93\%), and Ireland (+7.21\%). Still, in the other hand the weaker countries with most significant price declines were in Egypt (20.91\%), Turkey (-11.27\%), Dubai, UAE (-8.73\%), Kiev, Ukraine (-6.27\%), and Shanghai, China $(-4.49 \%)$, again using inflation-adjusted figures (Lalaine, 2018). Hence, Malaysia was not in the weaker country with price falls or deceleration it is just in between both category having stagnation markets, but it is still remained challenging for property developer firms. The Malaysia's property market is still stable did not show weaker or property's price falls but expects to be further stagnation unless otherwise hope and anticipation improvements to having some positive internal factors from the new Malaysia Government or external factor growing with global markets, eventually in May 2018 the changed of Malaysia Government with introduced new policies and incentives aimed to strengthen the property market but another hand the new Malaysia Government has stop most of the mega infrastructure projects that been awarded by previous Government which will affect the Malaysia construction market (Xue, 2019).

Malaysia's property market expected to be stagnation according to Bank Negara Malaysia (BNM) quarterly report 2017 showed the supply and demand imbalances in the property market have increased since 2015; the unsold property units mainly are residential properties with the price category above RM250,000.00 (Su, Stefanie, Muhamad and Le, 2017). At the third quarter of last year 2018, Malaysia has overhang unsold residential of 43,219 units worth RM29.47 billion, and Johor was the highest count holding overhang unsold units of 13,767 units, followed by Selangor 
Global Business Management Review, 2020

JUNE 2020

http://gbmr.oyagsb.uum.edu.my

(7,233 units) and Kuala Lumpur (5,114 units) (Xue, 2019). During the period of the stagnation property market in Malaysia, if 'S' remains existing outdated traditional marketing strategy and did not strengthen their marketing strategy to attract the new markets, it would be increasingly challenging and very critical for ' $\mathrm{S}$ ' business stainable.

\section{Property Development Industry}

Building is a basic human need to safeguard human life and health, and therefore people needs a building as protection shelter and some peoples even called a building as property and/or real estate (Zainul \& Amir, 2019). Therefore, property development markets are enormous and unlimited opportunities during economic booming upwards. The worldwide property market performance has been experiencing an upward, but there was a decline during the global economic crisis 1997 Asian financial crisis and 2008 to 2010 global financial crisis (Kepili \& Masron, 2016). In Malaysia property market most of the purchasers who purchased property is not for owner occupy, in fact, most investor will even purchase more than one unit as for investment purposes, commonly peoples believed building property is part of the most valuable investment factor that will provide long-terms value-added with property price appreciation in the same time can get a short-term return with renting the property (Zaid, Kiani \& Zainon, 2017). It will be better returned than the stock market without much volatility, and it has a high tangible asset value.

According to Department Statistic of Malaysia (DOSM), there were 17,447 establishments real estate services operators in 2015 compared to 2010 were only 8,277 establishments with a compound annual growth rate (CAGR) of $16.1 \%$. The value of gross output generated amounted to RM28.1 billion to the services; from the period of 2010 and 2015, there was an increase of RM9.4 billion registering a CAGR of $8.5 \%$. Furthermore, the value-added for real estate service recorded an increase of $8.8 \%$ per annum with a value of RM17.6 billion. (Figure 1) 
Global Business Management Review, 2020

JUNE 2020

http://gbmr.oyagsb.uum.edu.my

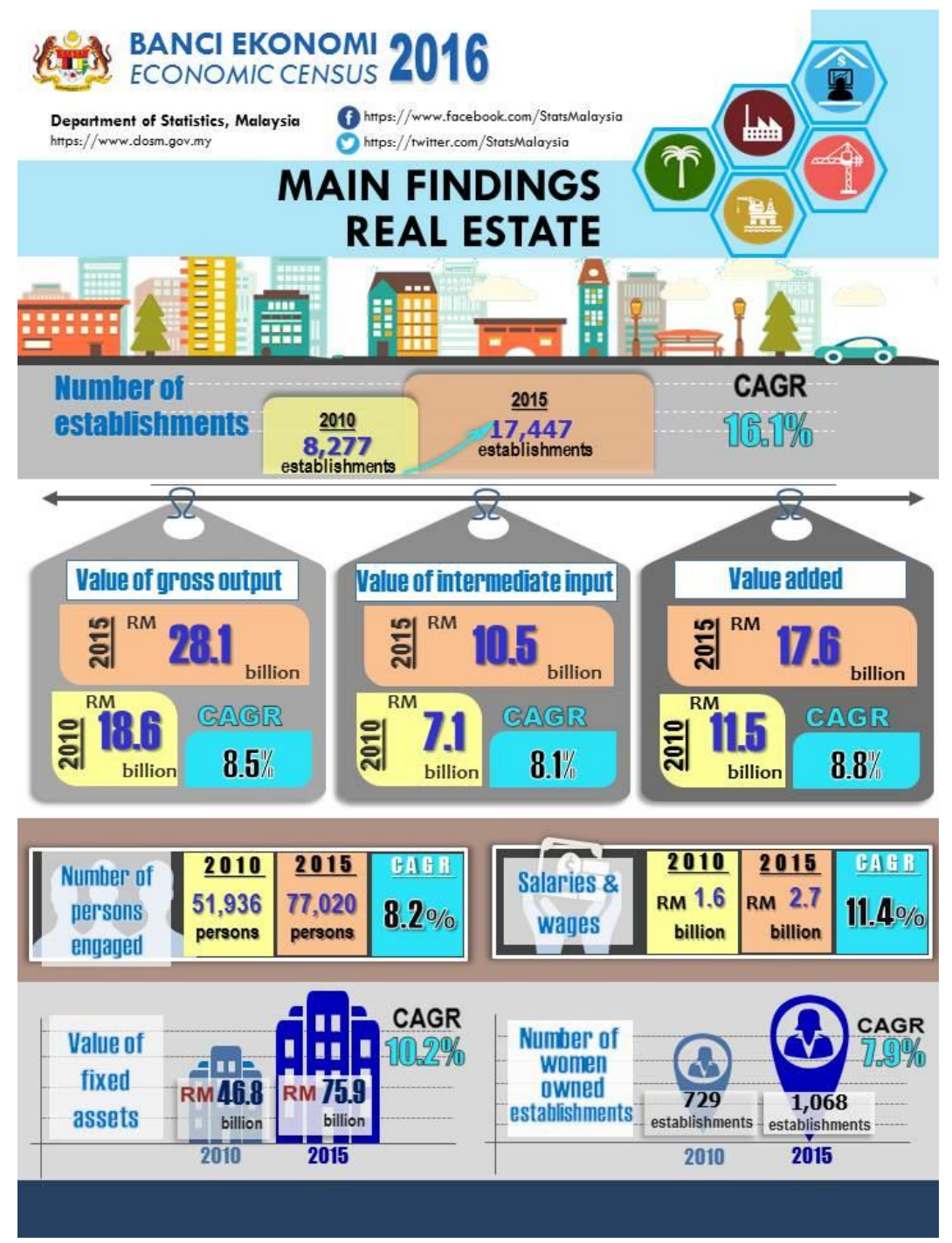

Source form Department of Statistic of Malaysia (2016)

Figure 1: Economic Census 2016 on Real Estate

Property investors were accepted greater risk with expected higher return as which property investors are still willing to invest even during the economic downturn; property investors were always using debt to purchase an investment property as can increase the return on the investor's equity (Nick, 2019). Therefore, marketing strategy is greatly important to promote the property products to investors and prospect purchasers, showing the property product's advantage and positive returns. Property development business is a highly competitive and challenging business in Malaysia, there are thousands of property developer companies in Malaysia some of the developer company are bankrupt with unsuccess abandon projects (Zaid, Kiani \& Zainon, 2017). 
Global Business Management Review, 2020

JUNE 2020

http://gbmr.oyagsb.uum.edu.my

Some sick projects were due to the failure of contractor and some were due to the problems of developer itself, most of the sick or abandon project are due to their companies' financial problems or project was increasing cost exceeded budget. As discovered, there are 235 sick projects in 2011 and 191 sick projects in 2013 (Jatarona, Yusof, Ismail, \& Saar, 2016).

\section{Company Background}

The 'S' company was founded since 1950's as a progressive building contractor with 'Class A' contractor registered under PKK and PAM as well as 'G7' classification under CIDB. Over the years, the company has built up capabilities as a foremost construction company; in the early 90's it has expanded its business into property development with building development projects in Klang Valley and East Malaysia in Sabah. It was listed on the Main Board of the Bursa Malaysia Securities Berhad in the property sector. Over the 60 years building experienced this company has built its reputation as a competent and reliable construction company primarily on the construction of high-rise buildings in Malaysia, having first established its brand as construction by building several of Kuala Lumpur's known landmark buildings.

According to the ' $S$ ' annual report, the company have unstable revenue over the year from 2005 to 2018, even loss of profit after taxation in the year 2007 and after ten years in 2017. In 2015 the company's Managing Director announced the group's main earnings in the coming years are contributors two coming projects as KL project, which has a potential GDV of about RM2 billion sprawled over 20 acres of land and another new mixed development project located at East Malaysia of Sabah over the 16 acres of land with gross development value (GDV) amount of RM1.8bil spread over the eight years. The up-coming projects with GDV over (RM) billions of megaprojects located, but the company still facing revenue decreased from RM152 million in 2015 to RM139 million and even lost RM3 million profit after taxation in 2017 which is impractically making lost even with both mega project GDV over RM1.8bil. The billions of GDV projects are still incomparable with the top 10 developer township projects. Still, it should not face revenue decreased, even making loss with the upcoming RM billion projects unless otherwise having a problem with the company management or marketing strategies. 
Global Business Management Review, 2020

JUNE 2020

http://gbmr.oyagsb.uum.edu.my

The ' $\mathrm{S}$ ' is public listed berhad company that listed in the Main Board of Bursa Malaysia Securities Berhad, but the company's management still used to run the company as small and medium scale of company with less than 60 staffs in the company for both mega projects. Only having five sales and marketing staffs and four sales admin staffs to handle all the sales and marketing cases for the company, all the sales were handling internally without appointing any of real estate agent to assist in the sales and marketing for both mega projects. The project staffs are considering the largest team for the company, which having 18 project staffs to manage the projects planning and construction execution site staffs for the both mega projects, follow with eight staffs for account and finance department. Others will be the office admin staff, HR department, property facilities staff handling maintenance and facilities of a completed project, and most importantly is the company top management and the board of directors of the company.

\subsection{CASE ANALYSIS}

Peoples do not have standard identical preferences, so it is rarely can have one product that completely satisfy everyone (Tang, Ng \& Skitmore, 2019), since there are different needs and expectation from different customers the ' $\mathrm{S}$ ' should have a strategic marketing approach to strengthening the marketing strategies plan with considering the marketing factors such as Marketing Positioning, Marketing Recognition, Diverse Customer Base, Marketing Strategies Effectiveness, Internal Environment, Promotion Strategies, Promotion Budgets, and Product Design and Technology, as the familiar modern marketing strategies with segmentation, targeting and positioning (STP) which can able to develop different demands to different homogeneous groups that have the similar demands and affordable level.

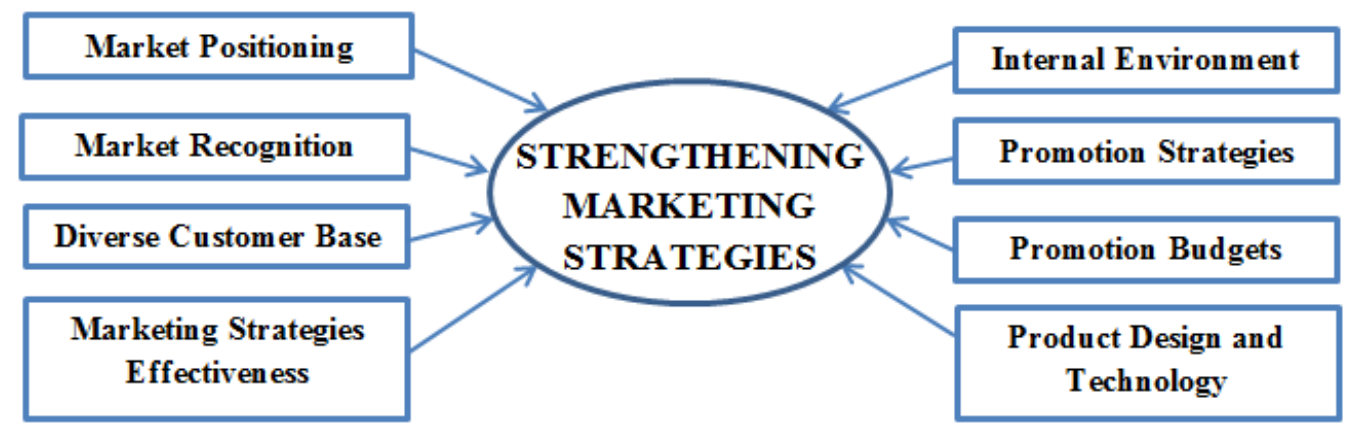


Global Business Management Review, 2020

JUNE 2020

http://gbmr.oyagsb.uum.edu.my

Figure 2: Factors to Strengthening Marketing Strategies

The marketing strategies are to focus on the customers' needs and wants and meet their expectations. Hence, a necessity need for any of the development strategies is the specification of the target markets that the products will attempt to serve (Muhammad, Azmi, Andrie \& Wina, 2020). The 'S' company may need to consider using target marketing which will usually break the market down into groups and to target the most profitable segments, inclusive the marketing mix elements such as products design and sizes, selling prices, amenities and facilities, promotional strategies, promotion budget, and others elements to suit the requirements of individual consumers. The company's internal environment and marketing efficiency are equally important for the marketing team makes the decision to develop the marketing strategies for the products they offer for sale. Therefore, the following marketing factors;

\section{Market Positioning}

The market positioning is becoming one of the fundamental components for the modern marketing strategies, a good market position can influence the consumer buyers' perception of the products and/or the company branding relatively comparable to the competitors (Saqib, 2019). Studies found positive relationship between company performance with profitability and efficiency. It becomes the main strategic factors to differentiate with the competitors' products and branding (Stavros, Markos \& Charles, 2000). Creating a competitive market position is essential for long term business success, but in the competitive markets to further understand the competitors' strengths and weaknesses are even equally important for marketing strategies development plans (Chen \& Uysal, 2002). Currently the 'S' does not have a proper marketing development plan with a strategic market positioning in the property development business, management did not emphasize marketing strategies for the market segmentation, targeting a market, and market positioning for the company.

\section{Market Recognition}

Market recognition is how the consumer buyers know your company products; it is to measure the level of awareness to your products and/or services provided, it is essential for a company to know 
Global Business Management Review, 2020

JUNE 2020

http://gbmr.oyagsb.uum.edu.my

how their prospect customers and/or consumer buyers level of awareness to the company's products because most peoples are likely to consider purchasing the products that they recognize or been brought or used before as repeated buyer (Vedula, York \& Corbett 2018). Any products with a higher level of market recognition and awareness will be advantages occupies as the 'Front of the mind' positioning. The correct products' position and/or branding are paramount to improve market recognition with the prospect customers, with high market recognition, the new prospective customers willing to purchase the products even they do not know the products feature and quality (Barth, Clinch \& Shibano, 2003). Still, they will trust the recognized brand and/or company of the products. The 'S' having robust market recognition in East Malaysia of Sabah with more than 60 years' experience in building industry as building contractor and even the first developer.

\section{Diverse customer base}

Effective business is general to generate profit and revenue by selling products or services; it is essential to maintained long-term relationships with existing customers but no longer enough. A successful business should not only focus retained existing customers should also considering diverse new customers market (Saqib, 2019). Especially for the property development business, the product of a building is considered a high-cost investment not easy to have repeat customers to keep buying the building as an investment. Therefore, diverse customer base is equally important which the sales of building property coming from more different customers and not just the existing repeated customers; additional new customers can contribute other sales and generate additional revenue. Diversity strategies are not the only limit to customer base but also can considering diverse products and services, diverse pricing strategies, diverse production methods, diverse promotional plans, and diverse channels of distribution make business sense and even diverse workforce (Wood, 2005). Businesses can expand across cultural and geographic boundaries with the advanced communication of e-commerce and multimedia advertisement, which are proper channels to a diverse customer with getting attention form the new prospective customers allow to reach the new customer base. 
Global Business Management Review, 2020

JUNE 2020

http://gbmr.oyagsb.uum.edu.my

\section{Marketing Strategies Effectiveness}

An effective marketing strategy is depending on how well is the marketing team planning and efficient execution the marketing plans to achieve business success, the effective marketing strategies plan is required for the effective marketing strategies have to target the specific audience and focus on key benefits (Fullerton, Brooksbank \& Neale, 2019). A marketing strategies effectiveness is not only involved marketing department effectiveness, but it is also related with the company organization effectiveness including the company management's effectiveness, whereas increased the internal organization culture can enhance internal organization effectiveness dimension and increased external culture will enhance the external market effectiveness dimension (Birgit, Bryan \& Robert, 2002). A well-organized marketing strategy is crucial for the marketing department. The marketing plan's effectiveness depends on how can be the team execute and implement effectively, The company's management was understood their marketing strategies effectiveness issues was existed for a long time when two years ago the management decided to appoint a new general manager of sales and marketing department, part of the management was still reluctant to change with restructuring the company culture with adopting the modern market trends.

\section{Internal Environment}

The internal environment is the component and various elements or departments within the organization; it inclusive the company culture, management team, employees and staff, work practice, and work practice (Prakash \& Srivastava, 2019). Generally, most of the company were only concerned with the external environmental influence such as economic, technological, sociocultural, political-legal, and international forces and together with the external factors consists of company competitors, customers, suppliers, regulators, unions, and owners, but less focus or forget about another important factor of the internal environmental influence. According to Becherer, Halstead and Haynes (2001) the internal environmental impact for small to medium-sized enterprises may be more important influences than external environment as the internal staffs' characteristics can play a very important role to determine the efficiency in implementation and execution of the marketing strategies plan. The most strategic marketing plan will also not be been success without a team of capable and efficient staffs to execute the marketing plan efficiently. 
Global Business Management Review, 2020

JUNE 2020

http://gbmr.oyagsb.uum.edu.my

The company management is important as internal environment to support and ensure the marketing team to execute the strategic marketing plan effectively. The marketing department did not have effective support by the management for the marketing events to promote their products. Part of the management still had traditional contractor's cost saving mentality thinking that doing events or launching are wasting money as it may have no direct impact to the sales, as they still believed all the previous products could be sold out without any major events and why now need to spend money to have events and launching a program. Becherer, Halstead, and Haynes (2001) agreed that internal environmental influence would be more important than the external environment.

\section{Promotion Strategies}

Promotion strategies is an attempt for marketing department to inform, persuade and influence the consumers to buy the products, such as promotion campaigns or events for create awareness that provide more information and getting prospect buyer to test and view the products as well as retaining loyal customers (Tan, Akram \& Sui, 2019). The promotion methods can combine the traditional advertisement, sales promotion with offer or discount, sales event and roadshow as well as the modern trends of social media and e-commerce to promote the products. Foxman, Tansuhaj and Wong, (1988) described sales promotion is an essential part for marketing strategies to communicate with the consumers, it can allow marketing team to determine how to create differentiation with sales promotions that add value to their products even though it is instead even more expensive than the competitors. The product value can be improved by promotion events; an innovative sale promotion strategy can create additional value and better awareness for the company as well as the products. The 'S' having traditional promotion methods with brochures and flyers, print advertising, loyalty and reward programs, mail-outs and letter drops, and company having promotion methods such as website and Facebook, but it is not updated.

\section{Promotion Budgets}

The best innovative and effective promotion activities will not be a success without support by the sufficient promotion budget, as promotional budgets are critical for marketing strategies, which should be allocated for greater effectiveness (Tan, Akram \& Sui, 2019). Most companies judge 
Global Business Management Review, 2020

JUNE 2020

http://gbmr.oyagsb.uum.edu.my

and allocate the promotion budget with the past performance of promotion activity; they expected to have an immediate effective performance with sales increase immediately for the money been spent for the promotion activities. Unfortunately, most of the promotion impact may not necessary having immediate effect to improve the product sales, the value and potential of the promotion should not only realize and force to stop at the short period immediately with the promotion activities as the promotion budget invested is potentially build the long-term promotional equity with allowing more significant ideas to grow over a period of years for products branding and positioning (Rita \& Moutinho, 1992). There are differences budgetary methods to determine promotion budgets such as affordable method, percentage sales method, competitive parity method, objective and task method and many more, normally property developer having a different method to determine the promotion budget merely using the overall project value to allocate marketing budget and base on last year's sales revenue as reference for coming year promotion budget. The company's management does not allocate any promotion budget for the marketing department for planning with their promotion activity; their marketing department has to repeatedly submit multiple promotion proposals to get management approval individually.

\section{Product Design and Technology}

The building is a shelter and protection for the user and meet user needs through spatial environmental and interaction with the surrounding, the building design is combination of architectural, engineering and technical aspect to complete design with innovative technology to meet the consumers need and expectation (Zainul \& Amir, 2019). The future trends of building design may consist of sustainable building, green building, and energy efficiency building to reduce energy expenditure or more environmentally conscious building products. Innovation products design and technology are equally important to all products especially electrical, electronic, and mechanical products, but product design and technology do not only consist of imagining, creating objects of the products, and usability of the products. Eventually, it is closely related to marketing strategies that can promote and lead the products to achieve market expectations and needs. Great innovative product design and technology will be the "feature" of the products; it is similar with building products to have the features and/or selling point of the building products (Bryant, Straker \& Wrigley, 2020). 
Global Business Management Review, 2020

JUNE 2020

http://gbmr.oyagsb.uum.edu.my

According to Hsu (2011), product design is closely related to the marketing department during the design development activity design and marketing departments; both should constantly interact and exchange information, as the sales and marketing department is frontline facing the customers with all the latest information and feedback from customers. The innovative product design and technology can transform an important factor for marketing factor to grow the market awareness and demands, similarly, for the building industry, a new building design and building technology are an important marketing factor to grow the customers' awareness and interest to purchase the building products (Bryant, Straker \& Wrigley, 2020). The environmental awareness was increasing globally even Malaysian were adopted and slowly considering environmental issues, hence the innovative building design such as sustainable building and green building technology is the upcoming trend for the building industry. But innovative technology products will always incur higher construction cost with the environmental friendly material that having certified green products will common known at least 30\% higher than normal building construction cost, eventually another innovative building system such as a smart home system which able to control the home security system and electrical switches with a mobile phone or any mobile devices which will be eventually $20 \%$ higher in construction cost and higher maintenance cost. Prathiba and Siva (2018) summarized that smart home system is a smart and intelligent home system which not only actively monitors home system but also the wellness of the elderly and will also send necessary alarms or signal to the caretakers or doctors during an emergency.

\subsection{DISCUSSION AND RECOMMENDATIONS}

The ' $S$ ' was one of the pioneer building players in Malaysia with over 60's years experienced in building-related business that having pleasant and interesting company experienced background, but unfortunately the management and marketing team did not focus and emphasize the positive advantage to enhance company perception and to promote projects and building products. Since the company having multiple on-going mega development projects, the board of director and management team should seriously consider to update and upgrade the company's current outdated inefficiency policy and outdated marketing strategies. As study finding that a modern strategic marketing plan is crucial to strengthening the company's marketing strategies and increase the project product sales which will impact the overall company's revenue and the profit. With 
Global Business Management Review, 2020

JUNE 2020

http://gbmr.oyagsb.uum.edu.my

considering the marketing factors such as marketing positioning, marketing recognition, diverse customer base, marketing strategies effectiveness, internal environment, promotion strategies, promotion budgets, and product design and technology. Accordingly, it is proposed that:

\section{Market Positioning}

A good market position can influence the consumer buyers' perception of the products and/or the company branding relatively comparable to the competitors (Saqib, 2019). The market segmentation and market targets for the new Sabah project has been determined by the project location and the compliant local authority requirements, the ' $S$ ' need to emphasize and inclusive into the marketing strategies with new positioning to have a strategic marketing plan with highlighting the pleasant 60's-year historical building related experience from contractor to become a responsive developer and professionally develop a project with the highest quality, reasonable price, and complete within the committed timeframe. The project location and building design of the mixed development project were planned to create a new Central Business District (CBD) to the town with extending from the old town as waterfront tourism attractive area with walking and/or cycling distance.

\begin{tabular}{|c|c|c|}
\hline Segmentation & Targeting & Positioning \\
\hline $\begin{array}{l}\text { 1. Sabah, East Malaysian in } \\
\text { Bomeo }\end{array}$ & $\begin{array}{l}\text { 1. Local Middle-High } \\
\text { incomer }\end{array}$ & 1. New CBD in town \\
\hline $\begin{array}{l}\text { 2. Commercial Mixed } \\
\text { Development }\end{array}$ & 2. Investor (Local/Oversea) & $\begin{array}{l}\text { 2. } 60 \text { 's Years Experienced in } \\
\text { Building Industry }\end{array}$ \\
\hline $\begin{array}{l}\text { 3. Waterfront Project } \\
\text { Tourism Attractive }\end{array}$ & 3. Tourism Businesses & $\begin{array}{l}\text { 3. High Quality with } \\
\text { Reasonable Price }\end{array}$ \\
\hline
\end{tabular}

Table 1: Marketing Strategies for Sabah project

\section{Market recognition}


Global Business Management Review, 2020

JUNE 2020

http://gbmr.oyagsb.uum.edu.my

Market recognition is how the consumer buyers know your company products (Vedula, York \& Corbett 2018). The 'S' has strong company background history profile with over 60 's years building related experience between building construction and property developer, it was additional advantage profile in Sabah market as the company was the first developer to build a high-rise condominium project within the town at Sabah in the year 2011. The company's marketing strategies should include a strong, experienced company background to highlight and introduce the historical experience to the public. Market survey research is necessary for the company to understand and know public awareness, it is an essential measure because buyers are likely to consider the company they recognize when thinking about a purchase the products especially building property is not a small decision. Some peoples may only afford to buy a house in their lifetime therefore they will definitely be buying a home with most recognition and reputable property developer. Consequently, the company background should strongly emphasize to gain confidence for the buyer and show how renowned and responsible property developer with over 60's year's sustainability business between building construction and property developer, which will gain higher reputation and market recognition with the company's sustainability and longevity of the branding.

\section{Diverse Customer Base}

A successful business should not only focus retained existing customers should also considering diverse new customers market (Saqib, 2019). Diverse customer base is another important factor that should consider; the marketing department should not only target the existing customer databases that have purchased their products previously. All marketing events should not only invite the existing customer through traditional email or phone call without advertising in the media or multimedia to the public for diverse customer base into new customers to promote the available products. Should consider modern marketing tools with new trends such as e-commerce or multimedia marketing through an internet website, Facebook, Instagram, etc. multimedia channels, management should also allow marketing budget for prepare podcasting on the project design and live casting on-site construction progress, together with a photo, video, and file-sharing in the multimedia to spread the project to the public which will help to build product awareness as 
Global Business Management Review, 2020

JUNE 2020

http://gbmr.oyagsb.uum.edu.my

well as diverse customer base through multimedia not only in Malaysia as the power of multimedia can spread the project to the World for foreign investors (Trusov, Bucklin \& Pauwels, 2009).

\section{Marketing Strategies Effectiveness}

A strategic marketing strategy plan is the priority to enhance and strengthening the company's marketing strategies (Fullerton, Brooksbank \& Neale, 2019). It begins from an appropriate modern marketing tool with multimedia can gain market recognition and a diverse new customer base then an internal factor to ensure the company's marketing efficiency and effectiveness problems, the marketing team is equally essential for implement the marketing plan efficiently and effectively. The management should monitor the internal marketing team's performance and effectiveness of implementing the strategic marketing plans; the marketing department was always shorthanded with only five sales and marketing staff handling the two multi billions mega projects in KL and Sabah. When management decided not going to increase staffs expand the internal marketing teams, which another solution is to consider outsourcing sales to the real estate agency with a commission to promote the products. During the global economic downturn in Malaysia without many foreign investors as most of the property developers have great promotion discount, rebate and/or free gift to attract buyers, the company has to work-out a better and more attractive promotion package with the strategic marketing plan to attract a buyer from the new customer base.

\section{Internal Environment}

Generally, most of the company were only concerned with the external environmental influence but less focus or forget about another important factor of the internal environmental influence (Prakash \& Srivastava, 2019). The 'S' was founded in 1950's as a progressive building contractor since then the internal environment as building contractor was becoming the culture of the company, some of the senior staffs who were working with the company for more than 30 years. Therefore, the 30 years working culture and behavior still maintain as building contractor. The management to consider restructure the organization with changing the internal environment and working culture to suit the modern markets to become modern property developer firms and not remained as a building contractor culture. Building contractor behavior was always thinking 
Global Business Management Review, 2020

JUNE 2020

http://gbmr.oyagsb.uum.edu.my

practicality usage of the building but did not considering the building design outlook, as well as the marketing plans to sale, sell the property products. The new modern property developer culture will change and improve the company's internal environment to have more new idea to upkeep the marketing effectiveness to target the modern markets.

\section{Promotion Strategies}

Promotion strategies is an attempt for the marketing department to inform, persuade and influence the consumers to buy the products (Tan, Akram \& Sui, 2019). The promotion strategies are also part of the marketing strategies plans during the stagnation property market in Malaysia as almost all property developers having an attractive promotion for their products, most commons package were the "0" zero down payment to own a house and having stayed to own package. Stay to own package is signing a contract with a developer to rent the property for five years and after five years, can convert the rental to become the down payment for buying the property. Existing the ' $\mathrm{S}$ ' company having some traditional promotion package with standard discounts or rebates to their existing property products, which were equal to the zero down payment packages like other developers did. Still, the company's promotion did not packaging property to advertise to the markets. The ' $\mathrm{S}$ ' should strongly recommend and promote the promotion packages through modern e-commerce marketing with a diverse customer base to gain more sales.

\section{Promotion Budgets}

The best innovative and effective promotion activities will not be a success without support by the sufficient promotion budget, hence promotion budget is strongly related to promotion strategies (Tan, Akram \& Sui, 2019). Every successful strategic marketing strategies was straightly related by the financial support with the marketing budget which should be allocated. Therefore, the promotion budget is one of the most important factors for strategical execution of promotion strategies. It is unable for the marketing department to successfully implement and/or execute promotion strategies without sufficient promotion budget to blueprint for the promotion with money spending that required to get the promotion message to the right target market and to bring in the sales. The management should allocate sufficient marketing budget for the marketing team to execute the strategic marketing plan with a strategic promotion for their property products and 
Global Business Management Review, 2020

JUNE 2020

http://gbmr.oyagsb.uum.edu.my

the promotion required to have financial support by promotion budgets, normally development projects will allocate marketing budget with 3\% - 5\% of the overall project value which including authority charges for marketing purpose, products advertisement, sales events, marketing expenses and also inclusive promotion budget or agency fees. During the economic down-turn and stagnation property market in Malaysia, the company's management should not reduce the promotion budget but increase at least another $1 \%-2 \%$ to strengthening marketing strategies with attracting more buyers with improved branding and keeping the name in front of prospects and customers.

\section{Product Design and Technology}

The innovative product design and technology can transform an important factor for marketing factor to grow the market awareness and demands (Bryant, Straker \& Wrigley, 2020). A great building design and innovative technology products will always incur a higher cost as most of the company claimed that the higher cost incur is due to the money been spent on their design and development and the uncommon new material been used. As of building industry the building of the innovation design and technology are contributed to the buildability and functionality of a building and similarly facing the same higher cost problem, as the construction cost of new innovative building technology or a building with certified green building index will be at least $30 \%$ higher than normal building construction cost with the green-certified building material. Eventually, a pleasant industry player with over 60's years' experience in building industry as a building contractor and property developer who should be able to reduce the construction cost to build a sustainable building with new building technology and/or green building with a reasonable construction cost. The ' $\mathrm{S}$ ' should consider to partnership or alliance with suppliers to develop new technology for sustainable building products as a feature and marketing selling point for the building products, such as an economic smart home system to control the home security system and electrical switches with a mobile phone or any mobile devices.

Furthermore, as Malaysian growing awareness of environmental issues, the ' $\mathrm{S}$ ' should also consider to adopt the concept of sustainability with sustainable building which can minimize the negative environmental impact with the buildings construction and operation, it can be efficiently and moderation use of building materials, energy, and eco-system. It is not only benefiting the 
Global Business Management Review, 2020

JUNE 2020

http://gbmr.oyagsb.uum.edu.my

environment but can also benefit the purchasers or who occupy the building such as reduce energy consumption, lower flow of water and reduce the waste runoff. Sustainable building concepts not only can adopt by the high cost mechanical and electrical equipment as the architectural and engineering design are also part of the important facts to build a building with getting the natural resources and environmentally friendly building materials (Zainul \& Amir, 2019).

\subsection{CONCLUSION}

This case study is to access and examine the marketing strategies for the traditional property developer firm in Malaysia and the study targeted the company name 'S', the study method of access and examine was a direct interview with the company's marketing team to elaborate the existing company's situation and current company's standard processes. This study examines with a strategic marketing approach to strengthen the ' $\mathrm{S}$ ' marketing strategies plan with considering the marketing factors such as marketing positioning, marketing recognition, diverse customer base, marketing strategies effectiveness, internal environment, promotion strategies, promotion budgets, and product design and technology.

In terms of the effects for the study on practitioners, the finding provide the traditional company to have better understand of the current company problem with the traditional marketing approach and further provide a solution for the traditional company especially the ' $\mathrm{S}$ ' company to strengthen the marketing strategies even during the economic downturn which able to strengthen and improve the company market share and reduce the burden with selling off the completed balance unsold stock units, as this traditional property developer firm need to upgrade, update and improvement their marketing strategies.

As conclusion, the finding of this case study is to provide a solution for the traditional property developer firm name of ' $\mathrm{S}$ ' to strengthen the marketing strategies with marketing factors such as market positioning, market recognition, diverse customer base, marketing efficiency issues, internal environment, promotion strategies, promotion budgets, and product design and technology. Its possibility works well even during the economic downturn which able to strengthen and improve the company market share and reduce the burden with selling off the completed balance unsold stock units, as this traditional property developer firm need to upgrade, update and 
Global Business Management Review, 2020

JUNE 2020

http://gbmr.oyagsb.uum.edu.my

improvement their marketing strategies. Nevertheless, the finding also offers indispensable research and practical implications as it shows the strengthening marketing strategy in traditional property developer firms, it is useful in gaining insight into traditional marketing issues that even affects most of the traditional companies in Malaysia or even others country of the world.

\subsection{REFERENCES}

Barth, M. E., Clinch G. \& Shibano T. (2003). Market Effects of Recognition and Disclosure, Journal of Accounting Research, 41(4), 581-609

Becherer, R. C., Halstead, D., \& Haynes, P. (2001). Marketing Orientation in SMEs: Effects of the Internal Environment. Journal of Research in Marketing and Entrepreneurship, 3(1), 117.

Bryant, S.,T., Straker, K., \& Wrigley, C. (2020). The rapid product design and development of a viable nanotechnology energy storage product, Journal of Cleaner Production, 244(2020), 118725 .

Chen, J. S., \& Uysal, M. (2002). Market Positioning Analysis. Annals of Tourism Research, 29(4), 987-1003.

Fullerton, S., Brooksbank, R. and Neale, L. (2019). Measuring the effectiveness of technologybased marketing strategies from the consumer perspective, European Business Review, $31(6), 813-830$.

Foxman, E. R., Tansuhaj, P. S., \& Wong, J. K. (1988). Evaluating Cross-National Sales Promotion Strategies: An Audit Approach. International Marketing Review, 5(4), 7-15.

Hsu, Y. (2011). Design innovation and marketing strategies in successful product competition. Journal of Business \& Industrial Marketing, 26(4), 223-236.

Jatarona, N. A., Yusof, A. M., Ismail, S., \& Saar, C. C. (2016). Public construction projects performance in Malaysia. Journal of Southeast Asian Research, 2016(2016), 1-7. 
Global Business Management Review, 2020

JUNE 2020

http://gbmr.oyagsb.uum.edu.my

Kepili, E. I., \& Masron, T. A. (2016). Malaysia property sector. International Journal of Housing Markets and Analysis, 9(4), 468-482.

Lalaine, D. C. (2018, December 1). Q3 2018: World's housing markets poised to slow, but strong house price rises continue in Europe and parts of Asia. Retrieved from https://www.globalpropertyguide.com/press-relations

M., Zaid, S., Kiani, Rad, A., and Zainon, N. (2017). Are green offices better than conventional? Measuring operational energy consumption and carbon impact of green office in Malaysia. Facilities, 35(11/12), 622-637.

Muhammad, R., A., P., Azmi B., H., Andrie P., H., and Wina S. (2020). Analyzing the Effect of Information Credibility towards Brand Trust in Green Marketing. International Journal of Psychosocial Rehabilitation, 24(2), 1649-1663.

Nick F., (2019). Property investment: gearing and the equity rate of return, Journal of Property Investment \& Finance, 37(3), 323-328.

Prakash, G. and Srivastava, S. (2019). Role of internal service quality in enhancing patient centricity and internal customer satisfaction, International Journal of Pharmaceutical and Healthcare Marketing, 13(1), 2-20

Prathiba U. \& Siva S. Y., (2018). Smart home for elder care using wireless sensor, Circuit World, 44(2), 69-77.

Rita, P., \& Moutinho, L. (1992). Allocating a Promotion Budget. International Journal of Contemporary Hospitality Management, 4(3), 3-8.

Saqib, N. (2019), A positioning strategy for a tourist destination, based on analysis of customers' perceptions and satisfactions: A case of Kashmir, India, Journal of Tourism Analysis: Revista de Análisis Turístico, 26(2), 131-151. 
Global Business Management Review, 2020

JUNE 2020

http://gbmr.oyagsb.uum.edu.my

Su Ling, C., Stefanie, A., Muhamad, S., \& Le Sze, L. (2017). Imbalances in the Property Market. $\begin{array}{lllll}\text { BNM } & \text { QUARTERLY } & \text { BULLETIN. } & \text { Retrieved }\end{array}$ http://www.bnm.gov.my/files/publication/qb/2017/Q3/3Q2017_fullbook_en.pdf

Tan, H., Akram, U. and Sui, Y. (2019). An investigation of the promotion effects of uncertain level discount: evidence from China, Asia Pacific Journal of Marketing and Logistics, 31(4), 957979.

Tang, Z., W., Ng, S., T., and Skitmore, M. (2019). Influence of procurement systems to the success of sustainable buildings. Journal of Cleaner Production, 218(2), 1007-1030.

Trusov, M., Bucklin, R. E., \& Pauwels, K. (2009). Effects of Word-of-Mouth Versus Traditional Marketing: Findings from an Internet Social Networking Site. Journal of Marketing, 73(5), 90-102.

Vedula, S., York, J. G., \& Corbett, A. (2018). Through the Looking-Glass: The Impact of Regional Institutional Logics and Knowledge Base Characteristics on Opportunity Recognition and Market Entry. Journal of Management Studies, 56(7), 1414-1451.

Xue Ying, T. (2019). Malaysia property market to see 'further stagnation' in 2019 - Rahim \& Co. Retrieved from https://www.theedgemarkets.com/article/property-market-see-furtherstagnation-2019-_-rahim-co

Wood. S. (2005). Leveraging diversity: A customer service strategies. Journal / American Water Works Association. 97(1), 47-104.

Zainul, A., N., and Amir, S., N. (2019). Engaging consultants in green projects: exploring the practice in Malaysia. Smart and Sustainable Built Environment, 8(1), 80-94.

Zull Kepili, E. I., \& Masron, T. A. (2016). Malaysia property sector. International Journal of Housing Markets and Analysis, 9(4), 468-482. 